\title{
Minimization of the Difference between the Theoretical Mean of the Rayleigh Probability Density Function and the Mean Obtained from its Plot
}

\author{
Mustafa Mutlu \\ Teknik Bilimler MYO \\ Ordu University 52200, Ordu, Turkey \\ *Corresponding Author: mustafamutlu@odu.edu.tr
}

Copyright (C) 2014 Horizon Research Publishing All rights reserved

\begin{abstract}
In this study, the difference between the mean of the Rayleigh Probability Density Function and the mean obtained from the graph of Rayleigh Probability Density Function is minimized by changing the coefficient in the equation yielding the mean. By using various numbers of data and $\mathrm{K}$ values, Rayleigh Probability Density Function is plotted with the means mentioned above.
\end{abstract}

Keywords Rayleigh Probability Density Function, Line of Sight, No Line of Sight

\section{Introduction}

Rayleigh Probability Density Function is used for the cases in which there is NLOS between transmitters and receivers for the communication networks and channel modeling. When there occur phase differences between multipath signals arriving the receiver, fading takes place. Rayleigh distribution function is used for multipath fading in modeling of change of voltage or power that will be received[1-8]. In Rayleigh modeling, in contrast to the Ricean, there is no any specified direction, that is, signals coming from any direction are assumed to have equal probability.

Moreover Rayleigh Modeling is used for noise analysis. If a signal coming to a receiver via reflection becomes so greater than the direct signal that it suppresses that, in this case this type of channel modeling is done by means of Rayleigh Probability Density Function.

The aim of our study is to find an expression which results in numerical values that are very close to the actual values. For this purpose after much iteration we have obtained a new coefficient that gives the desired results.

\section{Theory}

Rayleigh Probability Density Function changes with respect to a single parameter, either standard deviation or $\mathrm{K}$ [9-15] where $\mathrm{K}$ is the power of direct signal divided by the power of coming signal via reflection and expressed as

$$
\begin{aligned}
K & =P^{\prime} \text { los } / P^{\prime} \text { multipath } \\
K & =1 / 2 \sigma^{2} \\
P_{\text {los }}^{\prime}= & 0 \mathrm{Watt}=1 \mathrm{dBW}
\end{aligned}
$$

$\mathrm{K}$ characterizes the environment. $\mathrm{K}$ values are normalized when using in the equation(4).

Rayleigh Probability Density Function is expressed as

$$
f_{z}(z)=2 z K \exp \left(\left(-z^{2} K\right)\right)
$$

When $\mathrm{K}$ represents the Power

$$
\mathrm{L}=\mathrm{K} / 10
$$

and if it represents the voltage

$$
L=K / 20
$$

is used. For both cases,

$$
S=10^{L} .
$$

Normalized Rayleigh Probability Density Function can be written as

$$
f_{z}(z)=2 z S \exp \left(\left(-z^{2} S\right)\right)
$$

$\mathrm{S}$ is obtained through the equations (5), (6), (7) and used in equation (8) to obtain $\mathrm{f}_{\mathrm{z}}(\mathrm{z})$.

Mean of this function is

$$
f_{z}(z)(\text { mean })=M[z]=\int_{0}^{\infty} z f_{z}(z) d z,
$$

And theoretical mean can be written as,

$$
T M=M[z]=\left(\frac{1}{2}\right) \sqrt{\pi / K}=1.2533 \sigma
$$

And the variance is written as

$$
\sigma^{2}=M\left[z^{2}\right]-M^{2}[z]=(0.2146 / K)
$$


And the Standard deviation is

$$
\sigma=0.4632 / \sqrt{K}
$$

Table 1 shows the actual and theoretical means and percent error of theoretical mean.

Table 1. Actual and Theoretical Mean Values and Percent Errors.

\begin{tabular}{|c|c|c|c|}
\hline \multicolumn{5}{|c|}{ for 171 data } \\
\hline $\begin{array}{c}\text { Koltage } \\
(\mathrm{dB})\end{array}$ & $\begin{array}{c}\text { AM } \\
\text { Actual } \\
\text { mean }\end{array}$ & $\begin{array}{c}\text { TM } \\
\text { theoretical mean }\end{array}$ & Error(\%) \\
\hline 10 & 41 & 49.83 & 5.16 \\
\hline 12 & 36 & 44.44 & 4.93 \\
\hline 14 & 33 & 39.58 & 3.84 \\
\hline 16 & 29 & 35.28 & 3.67 \\
\hline 18 & 26 & 31.44 & 3.18 \\
\hline 20 & 23 & 28.02 & 2.93 \\
\hline
\end{tabular}

\section{Modification of Theoretical Mean Expression}

In equation (10) the coefficient $1 / 2$ is not suitable. Because there is a big difference between the actual and theoretical curves when theoretical mean is used for the plot of Rayleigh Probability Density Function. Instead we suggest a change in equation (10) to achieve more reasonable results. After many iterations the coefficient $1 / 2$ is replaced by $1 / 2.3589$ to minimize the difference between the theoretical mean(TM) and the actual mean (AM) which is obtained from the graph of Rayleigh Probability Density Function.

Since TM being a function of $\mathrm{K}$ is the theoretical mean, if and only if $\mathrm{K} 1$ is used instead of $\mathrm{K}$ in Rayleigh Probability Density Function its actual mean becomes TM. This is illustrated in Table 4.
Equation (14) can be used for finding K1 by replacing it in place of $\mathrm{K}$.

$$
\begin{aligned}
& \mathrm{f}_{1}(\mathrm{z})=2 z K 1 \exp \left(\left(-z^{2} K 1\right)\right) \\
& M M=M 1[z]=\left(\frac{1}{2.3589}\right) \sqrt{\pi / K}
\end{aligned}
$$

Where MM is the modified mean. As can be seen from Table1, and Table 2 for $\mathrm{K}=10 \mathrm{~dB} \mathrm{AM}=41, \mathrm{TM}=49.83$ $\mathrm{MM}=42$ is obtained. This shows that the equation (14) yields a value which is very close to the actual mean whereas the theoretical one (TM) is far from it.

Table 2. Actual and Modified Mean Values and Percent Errors

\begin{tabular}{|c|c|c|c|}
\hline \multicolumn{5}{|c|}{ for 171 data } \\
\hline $\begin{array}{c}\text { Koltage } \\
(\mathrm{dB})\end{array}$ & $\begin{array}{c}\text { AM } \\
\text { Actual } \\
\text { mean }\end{array}$ & $\begin{array}{c}\text { MM } \\
\text { Modified mean }\end{array}$ & $\begin{array}{c}\text { Error } \\
(\%)\end{array}$ \\
\hline 10 & 41 & 42 & 0.58 \\
\hline 12 & 36 & 37 & 0.58 \\
\hline 14 & 33 & 33.56 & 0.32 \\
\hline 16 & 29 & 30 & 0.58 \\
\hline 18 & 26 & 26.6 & 0.35 \\
\hline 20 & 23 & 23.76 & 0.44 \\
\hline
\end{tabular}

Since the variance and standard deviation values are derived from the mean, an erroneous mean causes wrong results in variance and standard deviation[16-23]. Therefore to obtain minimum difference between the actual and theoretical mean, we changed the coefficient value several times. As a result we reduced the percent error from 5.16 percent to 0.32 percent. The average of $\mathrm{x}$ number of data can be expressed as

$$
M M_{x}=\frac{\text { Data } x}{171} M M_{171}
$$

Where $\mathrm{MM}_{171}$ is the average value of 171 data.

In Table 3 peak values corresponding to AM and TM voltage differences (errors) are given.

Table 3. Actual and Theoretical Peak Values and the difference between them

\begin{tabular}{|c|c|c|c|c|}
\hline $\begin{array}{c}\mathrm{K} \\
(\mathrm{dB})\end{array}$ & $\begin{array}{c}\mathrm{K} 1 \\
(\mathrm{~dB})\end{array}$ & $\begin{array}{c}\text { Actualpeak } \\
\text { value off }(\mathrm{z})(\%)\end{array}$ & $\begin{array}{c}\text { theoretical peak value off }(\mathrm{z}) \\
(\%)\end{array}$ & $\begin{array}{c}\text { Voltage } \\
\text { difference }\end{array}$ \\
\hline 10 & 7.13 & 1.5252 & 1.4503 & 0.0749 \\
\hline 12 & 9.29 & 1.7112 & 1.6398 & 0.0714 \\
\hline 14 & 11.13 & 1.9199 & 1.8240 & 0.0959 \\
\hline 16 & 13.13 & 2.1545 & 2.0688 & 0.0857 \\
\hline 18 & 15.13 & 2.4174 & 2.3317 & 0.08423 \\
\hline 20 & 17.13 & 2.7117 & 2.6049 & 0.1068 \\
\hline
\end{tabular}


Table 4 shows the variations of $f_{z}(z)$ and $f_{1 z}(z)$..

Table 4. $\mathrm{f}_{\mathrm{z}}(\mathrm{z})$ and $\mathrm{f}_{\mathrm{z}}(\mathrm{z})$ values depending on $\mathrm{K}$ and $\mathrm{K} 1$ respectively

\begin{tabular}{|c|c|c|c|}
\hline $\mathrm{K}(\mathrm{dB})$ & $\mathrm{f}_{\mathrm{z}}(\mathrm{z})=2 \mathrm{z} \operatorname{Sexp}\left(-\mathrm{z}^{2} \mathrm{~S}\right)$ & $\mathrm{K} 1(\mathrm{~dB})$ & $\mathrm{f}_{\mathrm{lz}}(\mathrm{z})=2 \mathrm{z} \operatorname{S} 1 \exp \left(-\mathrm{z}^{2} \mathrm{~S} 1\right)$ \\
\hline 10 & $6.32 \mathrm{z} \exp \left(-\mathrm{z}^{2} 3.16\right)$ & 7.13 & $4.54 \mathrm{z} \exp \left(-\mathrm{z}^{2} 2.27\right)$ \\
\hline 12 & $7.96 \mathrm{z} \exp \left(-\mathrm{z}^{2} 3.98\right)$ & 9.29 & $5.82 \mathrm{z} \exp \left(-\mathrm{z}^{2} 2.91\right)$ \\
\hline 14 & $10.02 \mathrm{z} \exp \left(-\mathrm{z}^{2} 5.01\right)$ & 11.13 & $7.20 \mathrm{z} \exp \left(-\mathrm{z}^{2} 3.60\right)$ \\
\hline 16 & $12.61 \mathrm{z} \exp \left(-\mathrm{z}^{2} 6.30\right)$ & 13.13 & $9.06 \mathrm{zexp}\left(-\mathrm{z}^{2} 4.53\right)$ \\
\hline 18 & $15.88 \mathrm{zexp}\left(-\mathrm{z}^{2} 7.94\right)$ & 15.13 & $11.41 \mathrm{zexp}\left(-\mathrm{z}^{2} 5.7\right)$ \\
\hline 20 & $20 \mathrm{z} \exp \left(-\mathrm{z}^{2} 10\right)$ & 17.13 & $14.37 \mathrm{z} \exp \left(-\mathrm{z}^{2} 7.18\right)$ \\
\hline
\end{tabular}

Actual, theoretical, and modified Rayleigh Probability Density Functions are plotted according to different $\mathrm{K}$ and data values in Fig. 1 through Fig. 6.

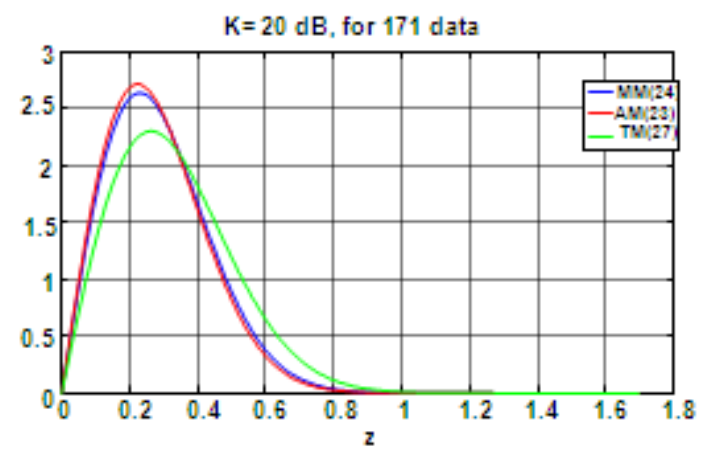

Figure 1. Plot of the Actual, Modified, and Theoretical Rayleigh Probability Density Functions

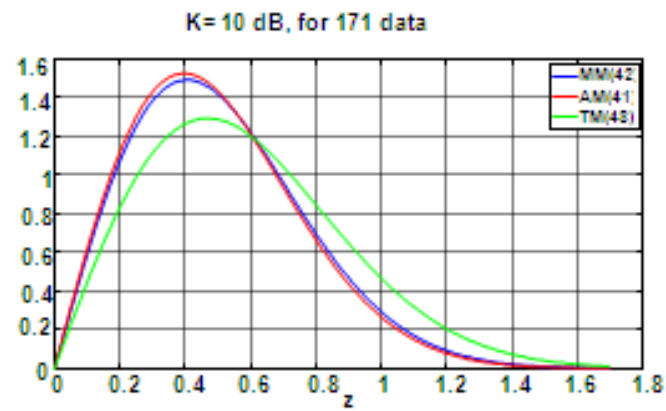

Figure 2. Plot of the Actual, Modified, and Theoretical Rayleigh Probability Density Functions

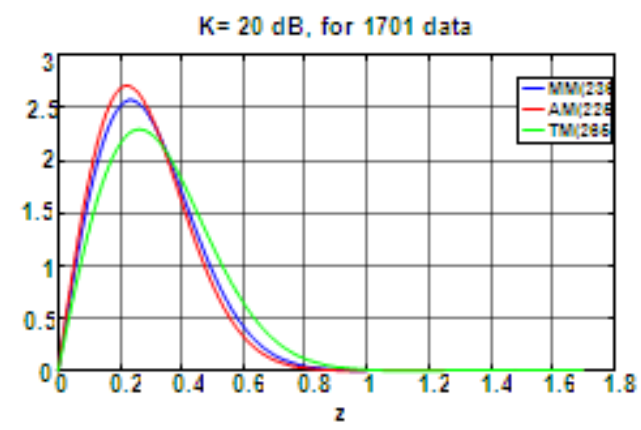

Figure 3. Plot of the Actual, Modified, and Theoretical Rayleigh Probability Density Functions

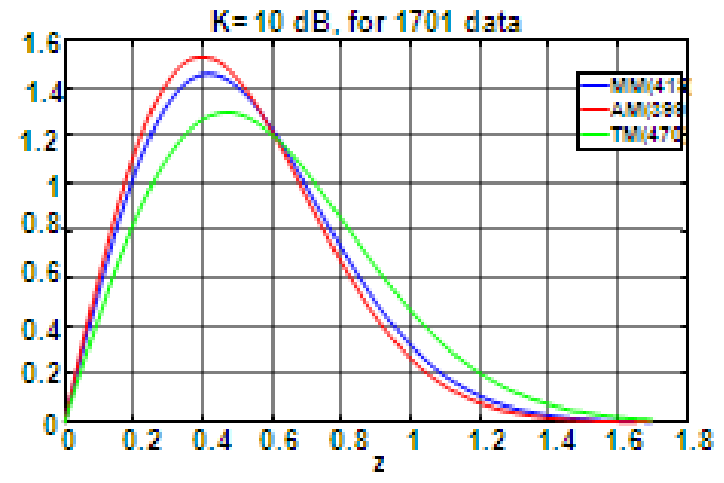

Figure 4. Plot of the Actual, Modified, and Theoretical Rayleigh Probability Density Functions

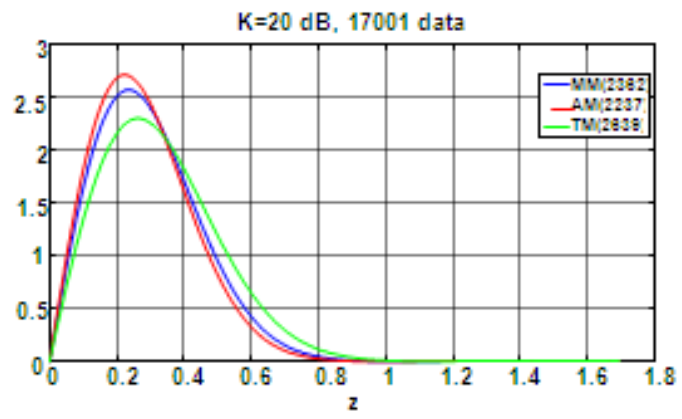

Figure 5. Plot of the Actual, Modified, and Theoretical Rayleigh Probability Density Functions

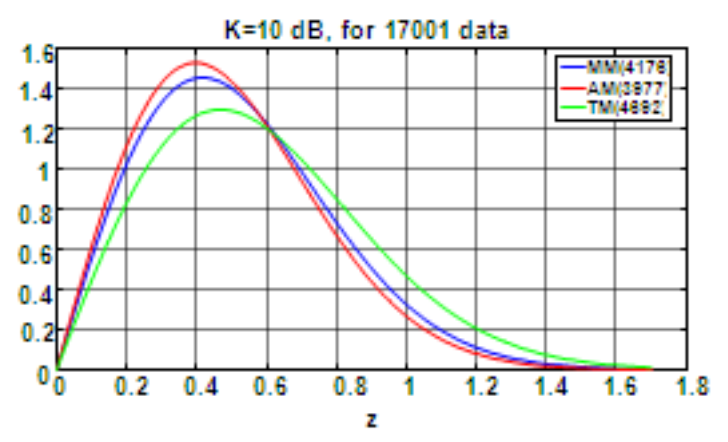

Figure 6. Plot of the Actual, Modified, and Theoretical Rayleigh Probability Density Functions 
Table 5. The mean values of $f_{z}(z), f_{1 z}(z), f_{2 z}(z)$ and their values around the means

\begin{tabular}{|c|c|c|c|c|}
\hline \multicolumn{5}{|c|}{$\mathrm{K}=20 \mathrm{~dB}$, for 171 data $\mathrm{AM}$} \\
\hline Data number & 22 & 23(mean) & 24 & 25 \\
\hline $\begin{array}{c}\text { Probability } \\
\text { value }\end{array}$ & 2.70224936 & 2.71177808 & 2.71029179 & 2.69828373 \\
\hline \multicolumn{5}{|c|}{$\mathrm{K}=20 \mathrm{~dB}$, for 171 data $\mathrm{MM}$} \\
\hline Data number & 23 & 24(mean) & 25 & 26 \\
\hline $\begin{array}{c}\text { Probability } \\
\text { value }\end{array}$ & 2.63034350 & 2.63552781 & 2.63075854 & 2.61649395 \\
\hline \multicolumn{5}{|c|}{$\mathrm{K}=20 \mathrm{~dB}$, for 171 data $\mathrm{TM}$} \\
\hline Data number & 26 & 27 (mean) & 28 & 29 \\
\hline $\begin{array}{c}\text { Probability } \\
\text { value }\end{array}$ & 2.29304064 & 2.29894371 & 2.29814705 & 2.29090434 \\
\hline
\end{tabular}

Table 6. The mean values of $f_{z}(z), f_{1 z}(z), f_{2 z}(z)$ and their values around the means

\begin{tabular}{|c|c|c|c|c|}
\hline \multicolumn{5}{|c|}{$\mathrm{K}=10 \mathrm{~dB}$, for 171 data $\mathrm{AM}$} \\
\hline Data number & 40 & 41(mean) & 42 & 43 \\
\hline $\begin{array}{c}\text { Probability } \\
\text { value }\end{array}$ & 1.52477789 & 1.52529002 & 1.52388460 & 1.52061275 \\
\hline \multicolumn{5}{|c|}{$\mathrm{K}=10 \mathrm{~dB}$, for 171 data $\mathrm{MM}$} \\
\hline Data number & 41 & 42(mean) & 43 & 44 \\
\hline $\begin{array}{c}\text { Probability } \\
\text { value }\end{array}$ & 1.49019207 & 1.49053635 & 1.48909413 & 1.48591223 \\
\hline \multicolumn{5}{|c|}{$\mathrm{K}=10 \mathrm{~dB}$, for 171 data $\mathrm{TM}$} \\
\hline Data number & 47 & 48(mean) & 49 & 50 \\
\hline $\begin{array}{c}\text { Probability } \\
\text { value }\end{array}$ & 1.29257103 & 1.29305214 & 1.29236036 & 1.29052165 \\
\hline
\end{tabular}

Table 7. The mean values of $f_{z}(z), f_{1 z}(z), f_{2 z}(z)$ and their values around the means

\begin{tabular}{|c|c|c|c|c|}
\hline \multicolumn{5}{|c|}{$\mathrm{K}=20 \mathrm{~dB}$, for 1701 data $\mathrm{AM}$} \\
\hline Data number & 224 & 225(mean) & 226 & 227 \\
\hline $\begin{array}{c}\text { Probability } \\
\text { value }\end{array}$ & 2.71246757 & 2.71247918 & 2.71238249 & 2.71217797 \\
\hline \multicolumn{5}{|c|}{$\mathrm{K}=20 \mathrm{~dB}$, for 1701 data $\mathrm{MM}$} \\
\hline Data number & 235 & 236(mean) & 237 & 238 \\
\hline $\begin{array}{c}\text { Probability } \\
\text { value }\end{array}$ & 2.57543251 & 2.57552531 & 2.57552503 & 2.57543207 \\
\hline \multicolumn{5}{|c|}{$\mathrm{K}=20 \mathrm{~dB}$, for 1701 data $\mathrm{TM}$} \\
\hline Data number & 264 & 265(mean) & 266 & 267 \\
\hline $\begin{array}{c}\text { Probability } \\
\text { value }\end{array}$ & 2.29939718 & 2.29941544 & 2.29936765 & 2.29925407 \\
\hline
\end{tabular}


Table 8. The mean values of $\mathrm{f}_{\mathrm{z}}(\mathrm{z}), \mathrm{f}_{1 \mathrm{z}}(\mathrm{z}), \mathrm{f}_{2 \mathrm{z}}(\mathrm{z})$ and their values around the means

\begin{tabular}{|c|c|c|c|c|}
\hline \multicolumn{5}{|c|}{$\mathrm{K}=10 \mathrm{~dB}$, for 1701 data $\mathrm{AM}$} \\
\hline Data number & 398 & 399(mean) & 400 & 401 \\
\hline $\begin{array}{c}\text { Probability } \\
\text { value }\end{array}$ & 1.52533995 & 1.52534257 & 1.52532591 & 1.52529002 \\
\hline \multicolumn{5}{|c|}{$\mathrm{K}=10 \mathrm{~dB}$, for 1701 data $\mathrm{MM}$} \\
\hline Data number & 417 & 418(mean) & 419 & 420 \\
\hline $\begin{array}{c}\text { Probability } \\
\text { value }\end{array}$ & 1.45500983 & 1.45501578 & 1.45500499 & 1.45497749 \\
\hline \multicolumn{5}{|c|}{$\mathrm{K}=10 \mathrm{~dB}$, for 1701 data $\mathrm{TM}$} \\
\hline Data number & 469 & $470($ mean $)$ & 471 & 472 \\
\hline $\begin{array}{l}\text { Probability } \\
\text { value }\end{array}$ & 1.29305056 & 1.29305723 & 1.29305214 & 1.29303533 \\
\hline
\end{tabular}

Table 9. The mean values of $f_{z}(z), f_{1 z}(z), f_{2 z}(z)$ and their values around the means

\begin{tabular}{|c|c|c|c|c|}
\hline \multicolumn{5}{|c|}{$\mathrm{K}=20 \mathrm{~dB}$, for 17001 data $\mathrm{AM}$} \\
\hline Data number & 2236 & 2237(mean) & 2238 & 2239 \\
\hline $\begin{array}{c}\text { Probability } \\
\text { value }\end{array}$ & 2.71248695 & 2.71248756 & 2.71248709 & 2.71248554 \\
\hline \multicolumn{5}{|c|}{$\mathrm{K}=20 \mathrm{~dB}$, for 17001 data $\mathrm{MM}$} \\
\hline Data number & 2361 & 2362(mean) & 2363 & 2364 \\
\hline $\begin{array}{l}\text { Probability } \\
\text { value }\end{array}$ & 2.56916919 & 2.56916947 & 2.56916883 & 2.56916727 \\
\hline \multicolumn{5}{|c|}{$\mathrm{K}=20 \mathrm{~dB}$, for 17001 data $\mathrm{TM}$} \\
\hline Data number & 2638 & 2639(mean) & 2640 & 2641 \\
\hline $\begin{array}{c}\text { Probability } \\
\text { value }\end{array}$ & 2.29941691 & 2.29941708 & 2.29941659 & 2.2994154 \\
\hline
\end{tabular}

Table 10. The mean values of $f_{z}(z), f_{1 z}(z), f_{2 z}(z)$ and their values around the means

\begin{tabular}{|c|c|c|c|c|}
\hline \multicolumn{5}{|c|}{$\mathrm{K}=10 \mathrm{~dB}$, for 17001 data $\mathrm{AM}$} \\
\hline Data number & 3976 & 3977(mean) & 3978 & 3979 \\
\hline $\begin{array}{c}\text { Probability } \\
\text { value }\end{array}$ & 1.52534367 & 1.52534384 & 1.52534381 & 1.52534359 \\
\hline \multicolumn{5}{|c|}{$\mathrm{K}=10 \mathrm{~dB}$, for 17001 data $\mathrm{MM}$} \\
\hline Data number & 4175 & 4176(mean) & 4177 & 4178 \\
\hline $\begin{array}{c}\text { Probability } \\
\text { value }\end{array}$ & 1.45292350 & 1.45292351 & 1.45292335 & 1.45292302 \\
\hline \multicolumn{5}{|c|}{$\mathrm{K}=10 \mathrm{~dB}$, for 17001 data $\mathrm{TM}$} \\
\hline Data number & 4691 & 4692(mean) & 4693 & 4694 \\
\hline
\end{tabular}

Table 5-Table 10 show the actual, modified and theoretical results for some data group. It can be seen from Table 1, Table 2, and Table 5 through Table 8, both TM and MM values are greater than AM values. 
Table 11. Percent errors according to various $\mathrm{K}$ and data numbers

\begin{tabular}{|c|c|c|c|}
\hline & for 171 data & for 1701 data & for 17001 data \\
\hline $\begin{array}{c}\mathrm{K} \\
\text { voltage } \\
(\mathrm{dB})\end{array}$ & Error(\%) & $\begin{array}{c}\text { Error } \\
(\%)\end{array}$ & $\begin{array}{c}\text { Error } \\
(\%)\end{array}$ \\
\hline 10 & 0.58 & 1.11 & 1.17 \\
\hline 12 & 0.58 & 0.76 & 0.78 \\
\hline 14 & 0.32 & 0.99 & 1.035 \\
\hline 16 & 0.58 & 0.88 & 0.98 \\
\hline 18 & 0.35 & 0.76 & 0.79 \\
\hline 20 & 0.44 & 0.64 & 0.73 \\
\hline
\end{tabular}

For a definite $\mathrm{K}$ value if the number of data increases percent error slightly increases as well.

\section{Conclusion}

In this study, to minimize the difference between the theoretical mean of Rayleigh Probability Density Function and the mean of the plot of Rayleigh function, we modified the equation (10) and obtained the equation (14) as the ultimate expression for the mean.

In actual plots and plots corresponding to theoretical means are shown together.

It is observed from the Table 11 that, for the smaller values of $\mathrm{K}$, percent error increases by the number of data much more than for the larger values of $\mathrm{K}$. For this particular study although the number of data increased 100 times, percent error was just only doubled.

\section{REFERENCES}

[1] A. Papoulis. Probability Random Variables and Stochastic Processes, McGraw-Hill, New York, 1965.

[2] J. Goldhirsh, W.J.Vogel. Handbook of Propagation Effects for Vehicular and Personal Mobile Satellite Systems, December, 1998.

[3] D. Lu, K. Yao. Improved Importance Sampling Technique for Efficient Simulation of Digital Communication Systems,IEEE Journal on Select. Areas in Commun.,Vol.6, No.1,67-75, 1988.

[4] W. C. Y. Lee. Mobile Communications Design Fundamentals, H. W. Sams and Co., Indianapolis, Indiana, 1986.

[5] M. Abramowitz, I. Stegun. Handbook of Mathematical Functions, NBS Applies Mathematics Series, Vol.55, U.S. Govt. Printing Office, Washington, DC.,20402,1964.

[6] R. H. Clarke. A Statistical Theory of Mobile-Radio Reception, Bell System Technical Journal, Vol.47, No.6, 329-339, 1968.

[7] W. C. Jakes. Microwave Mobile Communications, Wiley, NewYork, 1974.
[8] A. Maaref, S. Aissa. Joint and Marginal Eigen value Distributions of (Non)Central Complex Wishart Matrices and PDF-Based Approach for Characterizing the Capacity Statistics of MIMO Ricean and Rayleigh Fading Channels. Wireless Communications, IEEE Transactions on Vol.6, No.10,3607-3619,2007.

[9] B. Yang, K. B. Letaief, R. S. Chen, Z. Cao. Channel estimation for OFDM transmission in multipath fading channels based on parametric channel modeling, IEEE Trans. Commun., vol.49, 467-478, 2001.

[10] X. Ma, G. B. Giannakis, S. Ohno.Optimal training for block transmissions over doubly-selective wireless fading channels, IEEE Trans.Signal Processing, vol.51, 1351-1366, 2003.

[11] G.A. Dimitrakopoulos, C.N. Capsalis. Statistical modeling of RMS-delay spread under multipath fading conditions in local areas Vehicular Technology, IEEE Transactions on Vol.49, No.5, 1522-1528, 2000.

[12] J. Salo, H.M. El-Sallabi, P. Vainikainen. The distribution of the product of independent Rayleigh random variables. Antennas and Propagation, IEEE TransactionsVol.54,No.2, 639-643, 2006.

[13] B. Rivet, L. Girin,C. Jutten. Log-Rayleigh Distribution: A Simple and Efficient Statistical Representation of Log-Spectral Coefficients Audio, Speech, and Language Processing, IEEE Transactions on Vol.15, No.3, 796-802,2007.

[14] C.Yunxia, C. Tellambura. Joint distribution functions of three or four correlated Rayleigh signals and their application in diversity system analysis. Global Telecommunications Conference. Vol.5, 3368-3372, 2004.

[15] D.A.Abraham, A.P.Lyons. Exponential scattering and K-distributed reverberation. OCEANS,MTS/IEEE Conference and ExhibitionVol.3, 1622-1628,2001.

[16] P.M. Shankar. Outage probabilities in shadowed fading channels using a compound statistical model, Communications, IEE ProceedingsVol.152, No.6, 828-832, 2005.

[17] D. Kaplan, Ma. Oinglin. On the statistical characteristics of log-compressed Rayleigh signals: theoretical formulation and experimental results, Ultrasonics Symposium,Vol.2, 961-964, 1993. 
[18] J. Lei, Y. Tan. Geometrically Based Statistical Channel Models for Outdoor and Indoor Propagation Environments Vehicular Technology, IEEE Transactions on Vol.56, No.6, 3587-3593, 2007.

[19] H.Lu,Y.Chen,N. Cao. Accurate Approximation to the PDF of the Product of Independent Rayleigh Random Variables Antennas and Wireless Propagation Letters, IEEE Vol.10, 1019-1022, 2011.

[20] D.Wong, D.C. Cox. Estimating local mean signal power level in a Rayleigh fading environment, Vehicular Technology, IEEE Transactions on Vol.48, No.3, 956-959, 1999.
[21] R. Narasimhan, D.C. Cox.Mean and variance of the local maxima of a Rayleigh fading envelope, Communications Letters, IEEE Vol.4, No.11, 352-353, 2000.

[22] C. Gao, M. Zhao, S. Zhou, Yan Yao.A new calculation on the mean capacity of MIMO systems over Rayleigh fading channels, Personal, Indoor and Mobile Radio Communications, 14th IEEE Proceedings, Vol.3, 2267-2270, 2003.

[23] M. M. Peritsky. Correction to Statistical Estimation of Mean Signal Strength in a Rayleigh-Fading Environment, Communications, IEEE Transactions on Vol.22, No.10, $1733-1734,1974$. 